\title{
Application of reaction method based on the meanings hidden in overt behaviors and its effect on marital adaptability
}

\author{
Ahad Solatpetloo $^{1}$, Shahram Vaziri ${ }^{1 *}$, Farah Lotfikashani $^{1}$ \\ 1. Department of Psychology, Roudehen Branch, Islamic Azad University, Roudehen, Iran \\ Received: 22 September 2021 \\ Accepted for publication: 27 October 2021 \\ [EPub a head of print-7 Novmeber 2021] \\ Payesh: 2021; 20 (6): 719 - 729
}

\begin{abstract}
Objective (s): The present study aimed to examine a method focused on reacting based on the hidden meanings of overt behaviors and its effect on marriage adaptability.

Methods: This was a quasi-experimental study. Participants were sixty clients referred to psychological and counseling centers in Karaj, Iran with marital adjustment problems. They were selected by convenience sampling method and randomly assigned into two groups of fifteen pairs: experimental and control groups. The Spanier Dyadic Adjustment Scale (DAS), was used to collect information about research variables. Couples in the experimental group received a combination of self-monitoring and self-regulatory therapy for ten sessions to modify their communication actions. The control group only received the usual care. Results: The results showed that compared to the control group, marital adaptability significantly improved in the experimental group at post-treatment and at two-months follow-up assessments $(\mathrm{p}<0.05)$.

Conclusion: The findings suggest that method of reacting based on the hidden meanings of overt behaviors using the model of self-monitoring and self-regulation could be effective.
\end{abstract}

Keywords: react, hidden meanings, overt behaviors, adaptability, marital adaptability

\footnotetext{
* Corresponding author: Department of Psychology, Roudehen Branch, Islamic Azad University, Roudehen, Iran

E-mail: shahram.vaziri@gmail.com
} 


\title{
كاربرد روش واكنش دهى بر مبناى معانى نهفته در رفتار هاى آشكار و تاثير آن بر انطباق بذيرى زناشويى
}

\author{
احد صولت پتلو'، شهرام وزيرى '، فرح لطفى كاشانى' \\ 1. كروه روانشناسى، واحد رودهن، دانشعاه آزاد اسلامى، رودهن، ايران

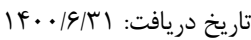

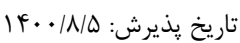

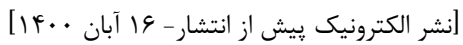

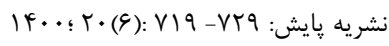

جـكيده

مقدمه: مبانى اصيل علم روانشناسى در جستجوى كشف و سازماندهى عوامل درون روانى موثر بر تعامل انسانها، بـهـ منظــور تنظـيم سـازكًارى و تـامين

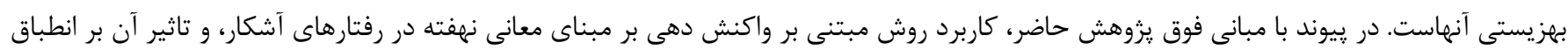
يذيرى زناشويى را مورد مطالعه قرار داده است.

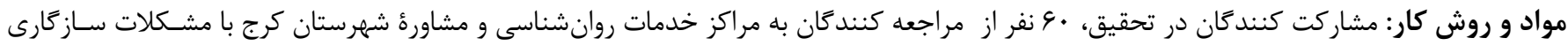

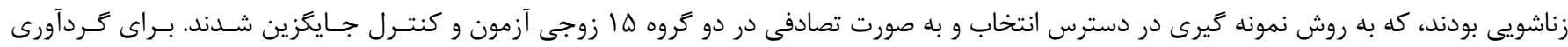

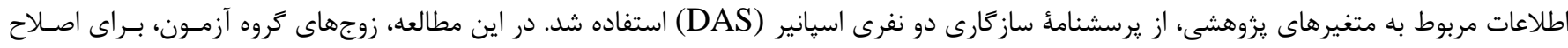

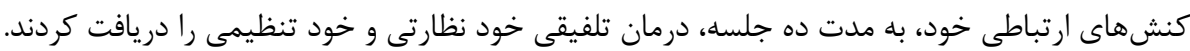

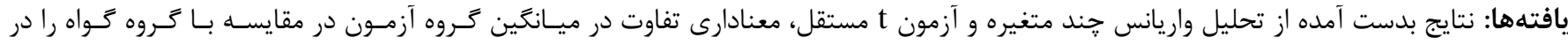

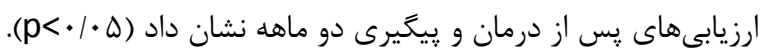

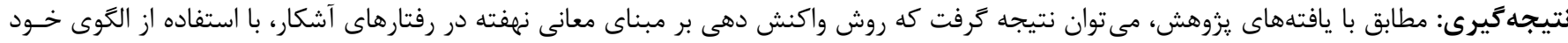

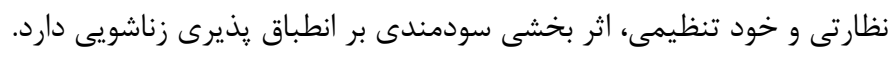
كليد وازه: واكنش دهى، معانى نهفته، رفتارهاى آشكار، انطباق پذيرى، انطباق يذيرى زناشويى 


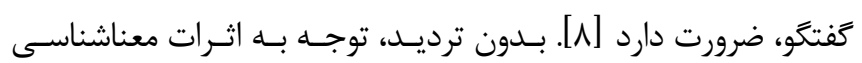

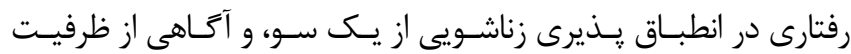

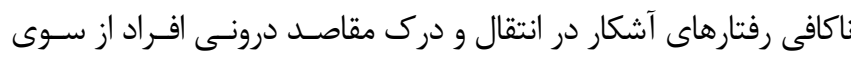

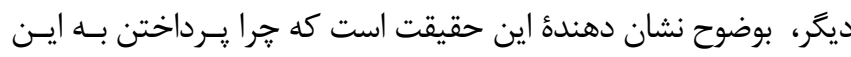

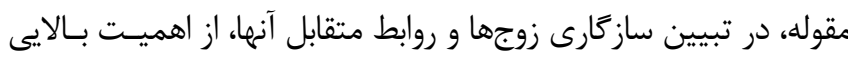

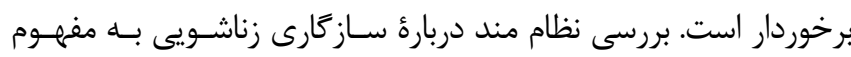

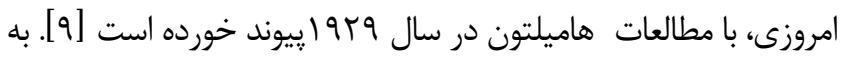
طور خلاصه، انطباق يذيرى يا ساز كارى زناشويى به عنسوان فراينـدى در

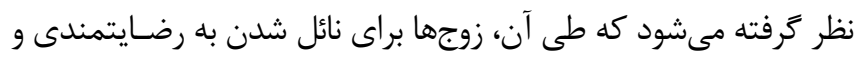

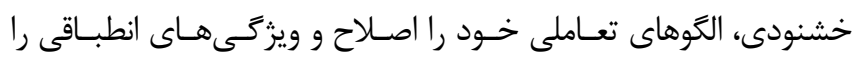

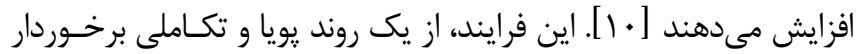

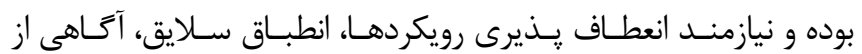

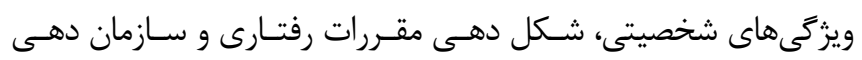

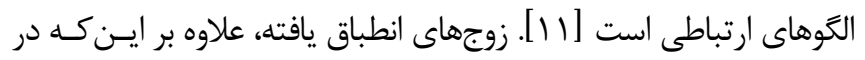

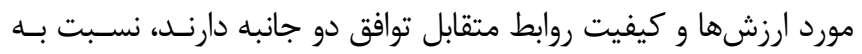

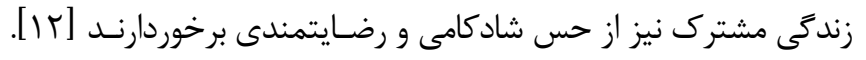

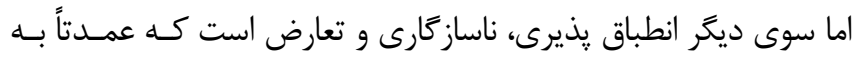

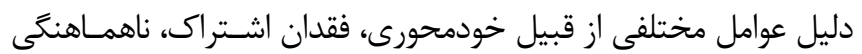

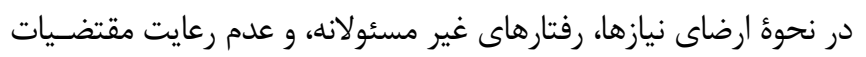

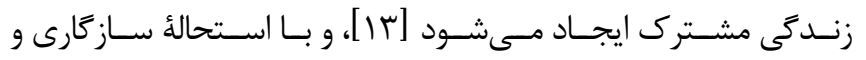

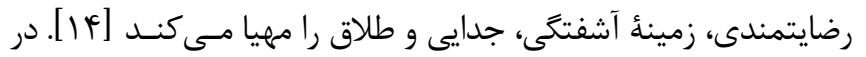

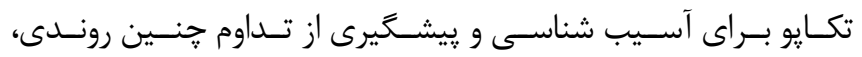

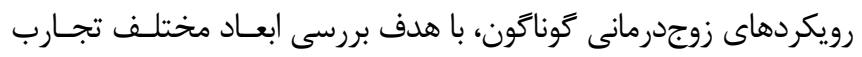

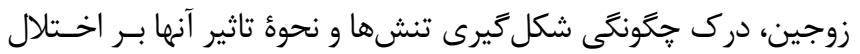

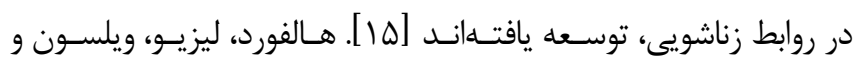

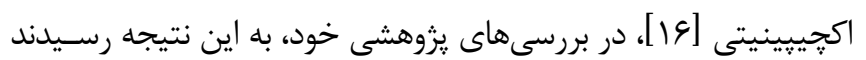

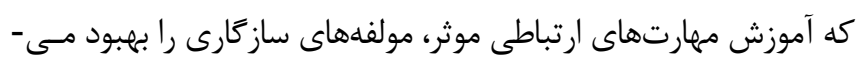
بخشد و به تنظيم رفتارى زوجها كمك مي كند. تحقيقاتى كه به بر بررسى

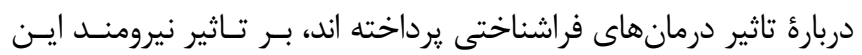

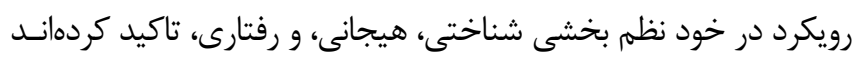

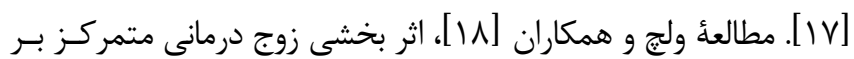

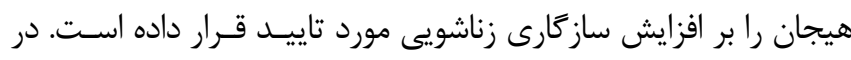

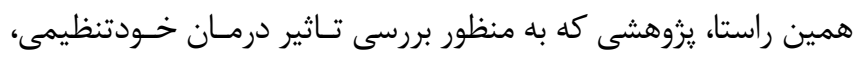

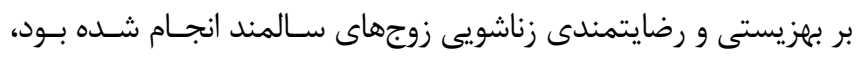

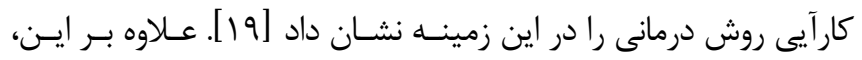

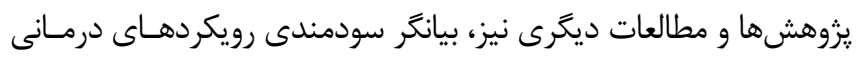

\section{مقدمه}

آيا انسان همان كونه عمل مى كند كه هسـت و مسىانديشـــ؟. بـا انـدكى

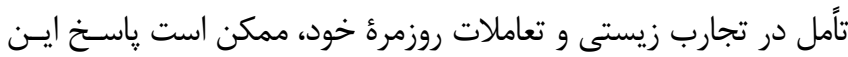

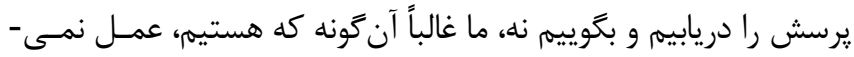
كنيه. در حالى كه دوست داريم، ابراز تنفر مى كنيه. در حسالى كـهـ نيـاز

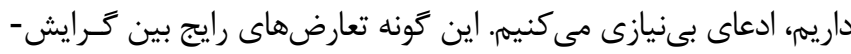

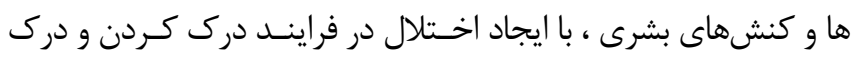

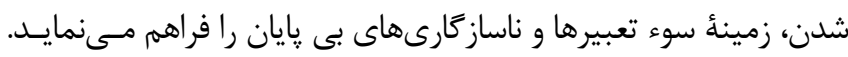

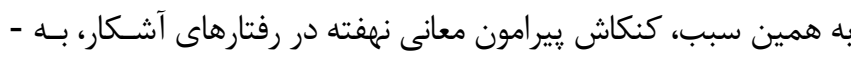

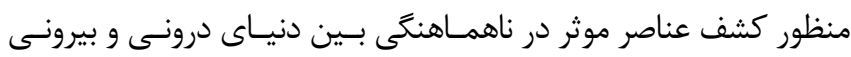

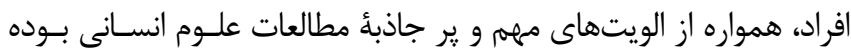

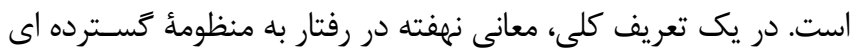

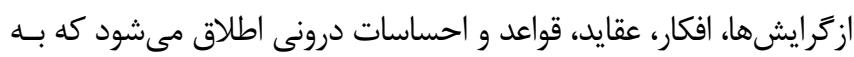

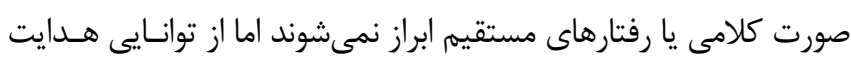

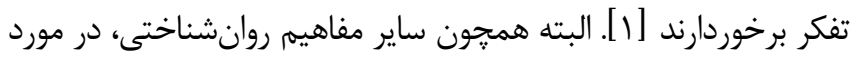

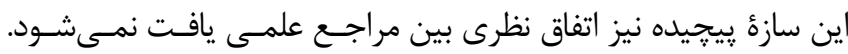

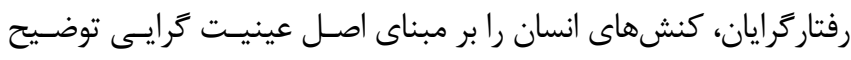

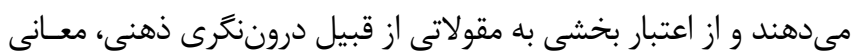

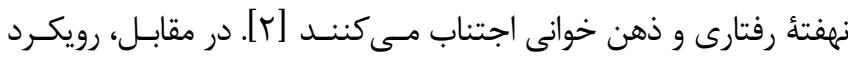

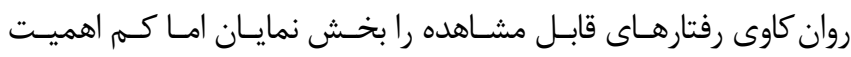

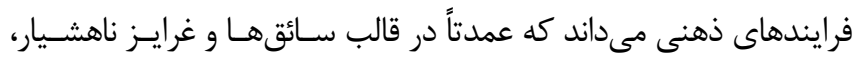

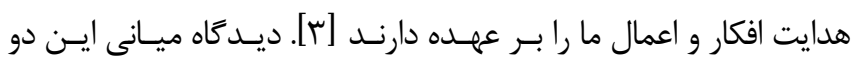

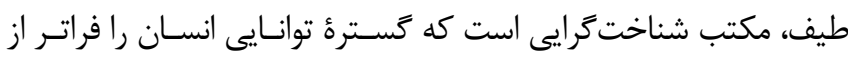

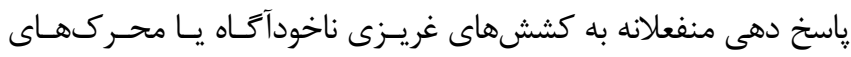

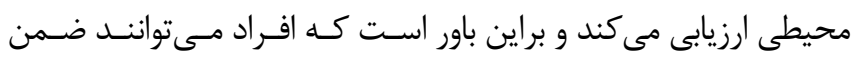

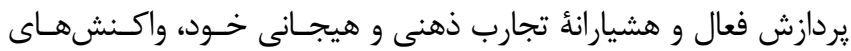

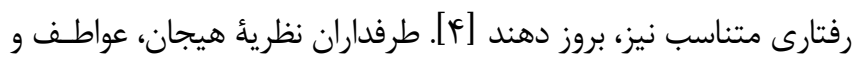

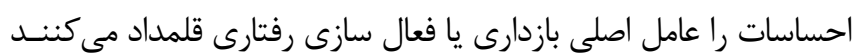

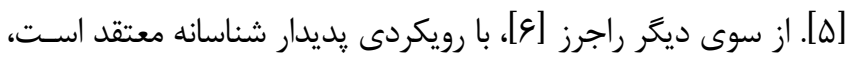

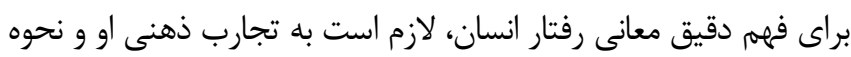

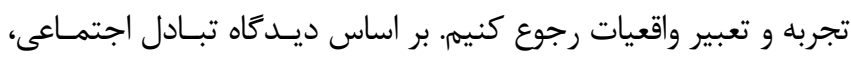

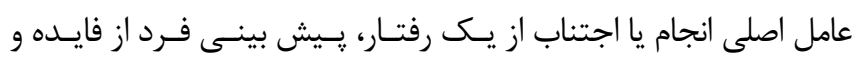

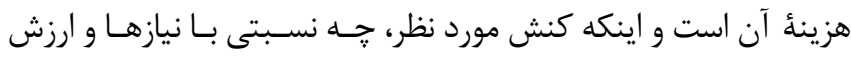

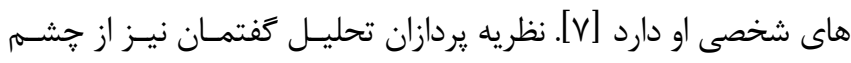

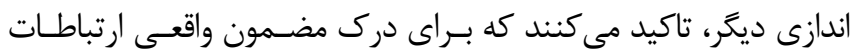

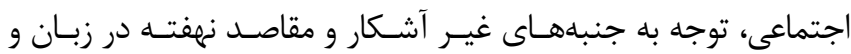


كانون اصلى مشكل و محل طلايى قرار درمانكران، همين نقطهاى باشــــ

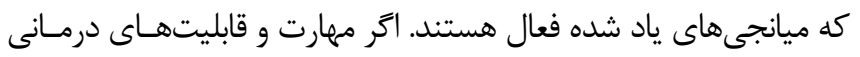

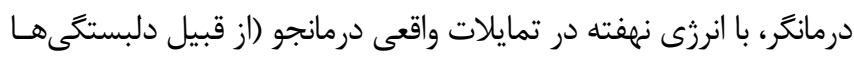
و نيازهاى اصيل)، به درستى تركيب شود و اين تركيسب در همراهـى بـ بـا

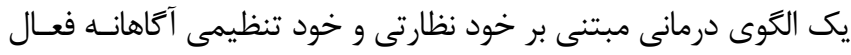

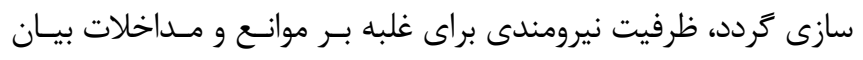

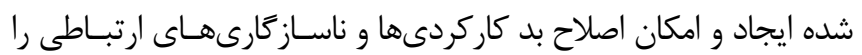

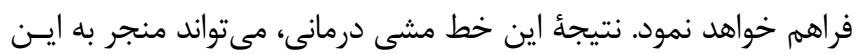

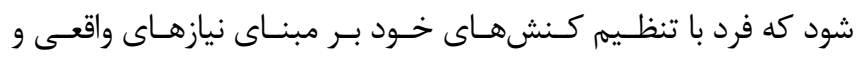

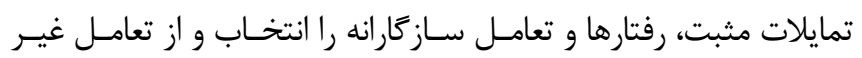

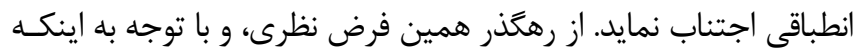

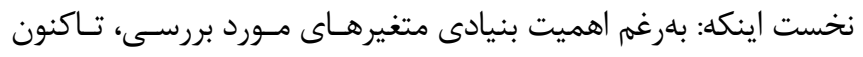

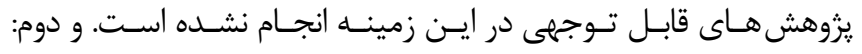

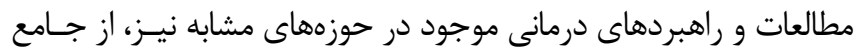

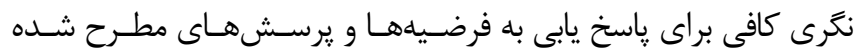

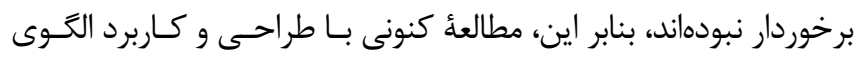

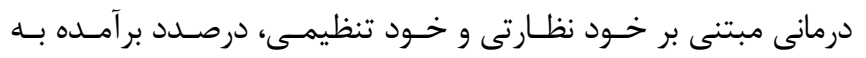

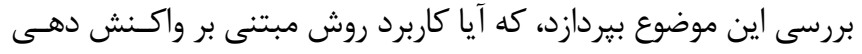

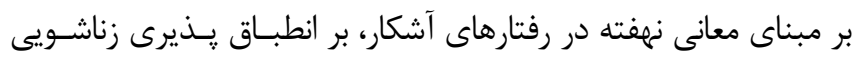

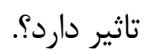

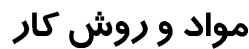

اين يزوهش از نوع نيمه تجربى قبل و بعد همـراه بـا حـروه كنتــرل

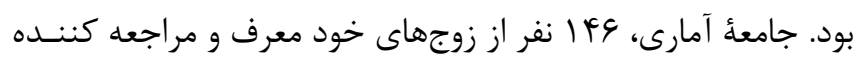

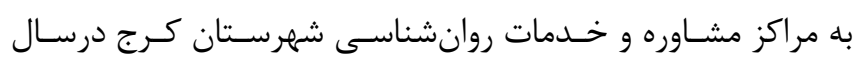
99 1 بودند كه از آسيبهاى ناشى از عدم انطباق يذيرى در روابـط

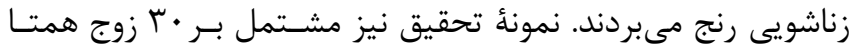

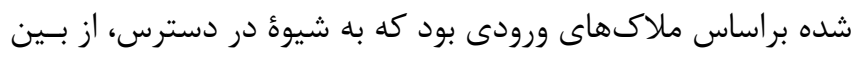

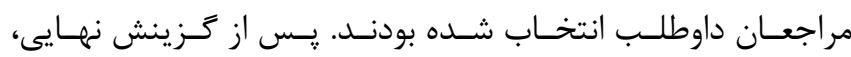

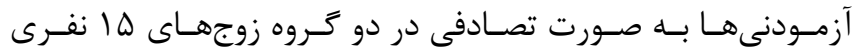

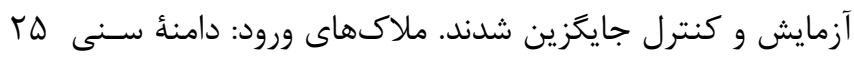

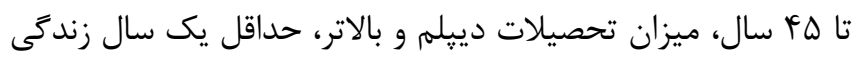

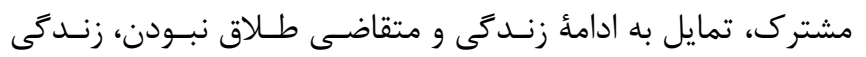

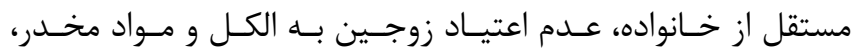

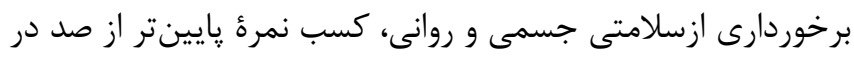

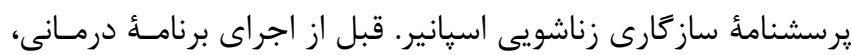

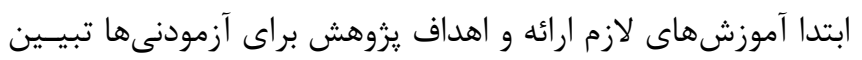

مختلف از جمله: درمان شـناختى - رفتـارى بــر مولفـهـــاى سـازكًارى

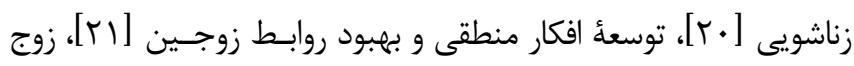

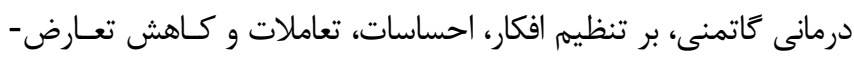

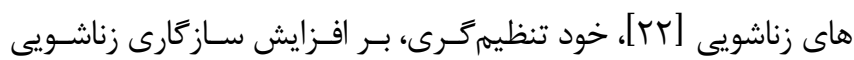

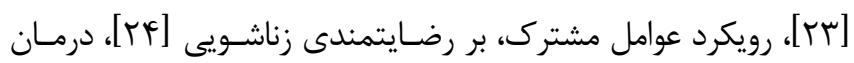

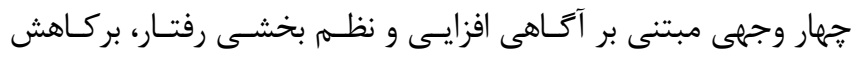

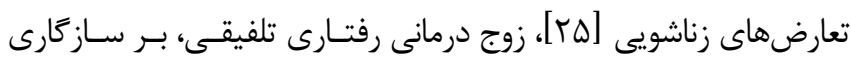

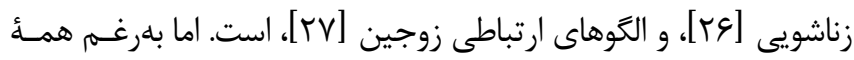

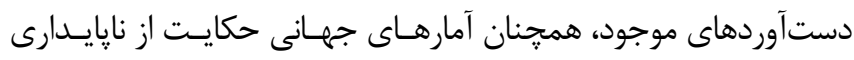

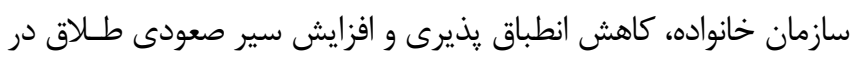

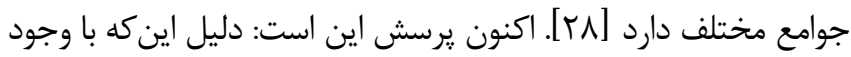

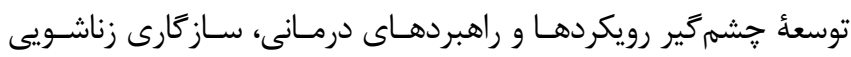

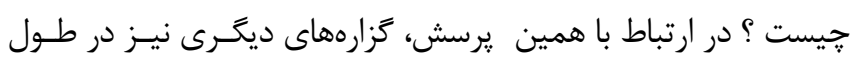

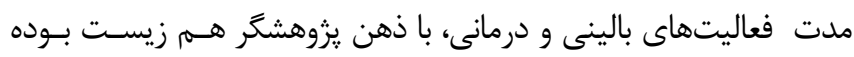

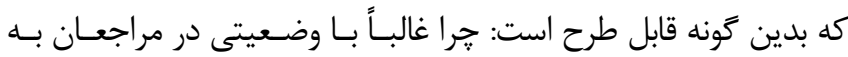

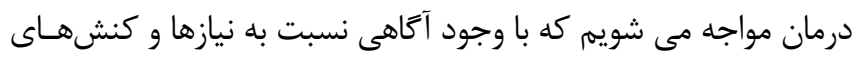

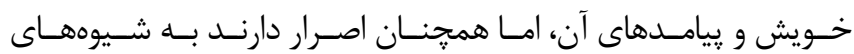

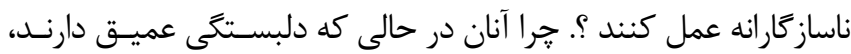

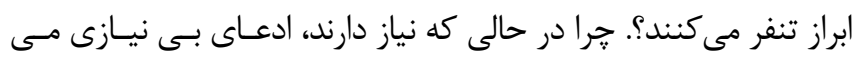

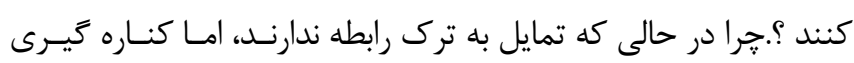

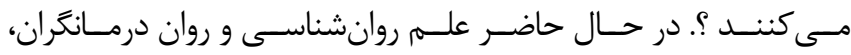

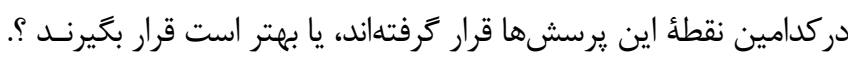

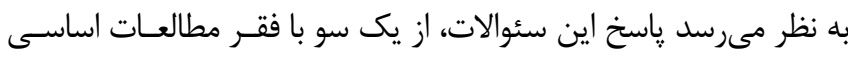

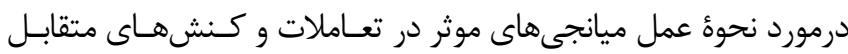
زوجين، و از سوى ديكر با عدم جامعيت نظرى و راهبردى رويكردهـاى دردي

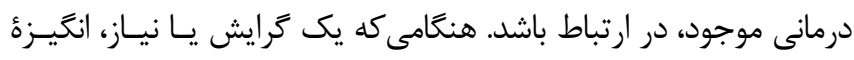

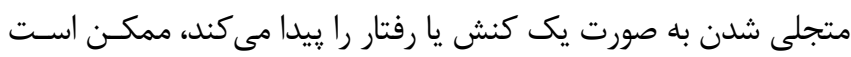

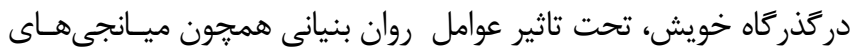

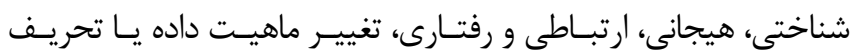

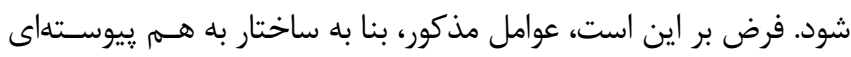

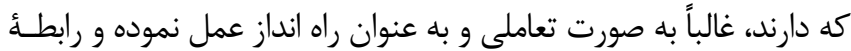
بين كرايش، يردازش و كنش را تضعيف يا تقويت مىنماينـد. همجنــين

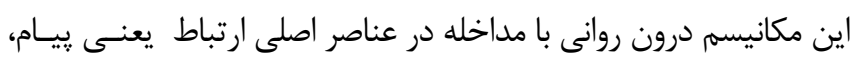

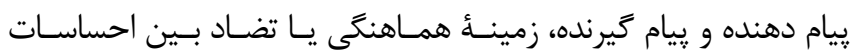

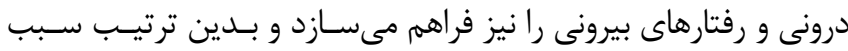

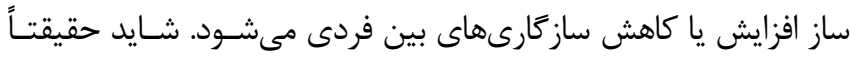


انجام شد. همجنين بـراى مقايسـة ميـانكَينهـاى گَروه آزمـايش و

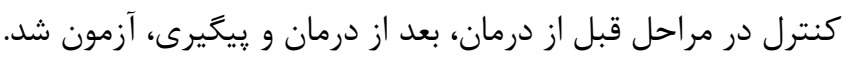

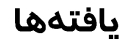

با توجه به ماهيت يزوهش و عوامل مرتبط با متغيرهاى آن، ويزگى -

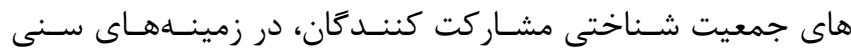

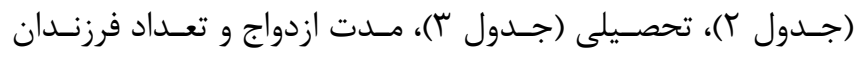
(جدول \&))، بررسى و نتايج بدست آمده به شرح زير ارائه شده است.

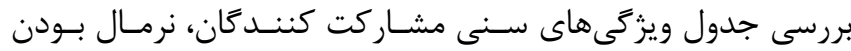

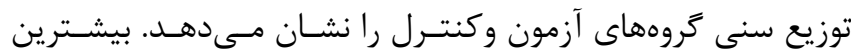

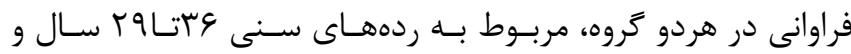

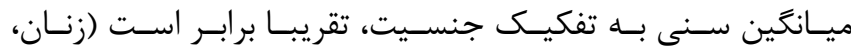
• متوجه مىشويم سطح تحصيلات هـردو حـروه كنتــرل و آزمـون، از

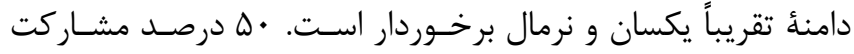

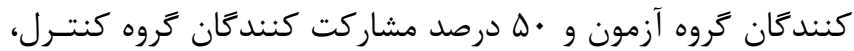

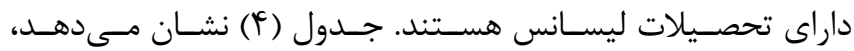

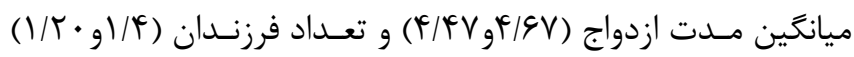

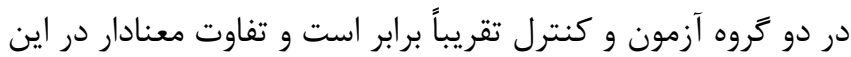

زمينه مشاهده نمى شود.

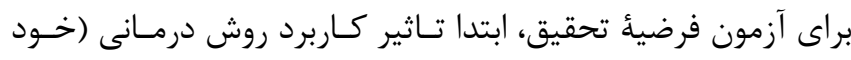

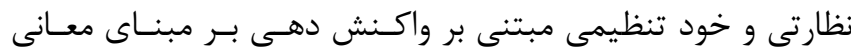

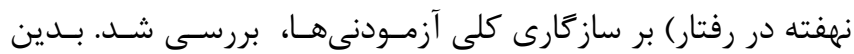

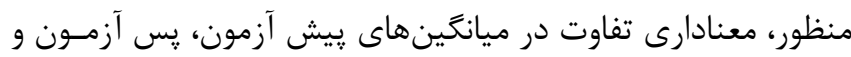

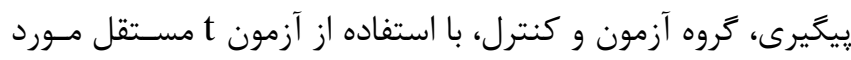

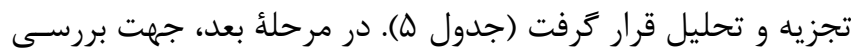

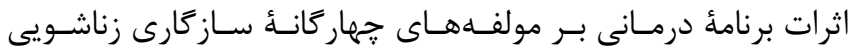

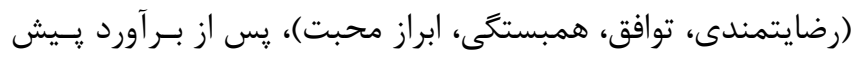

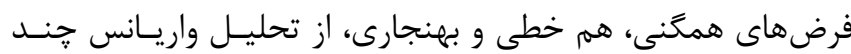

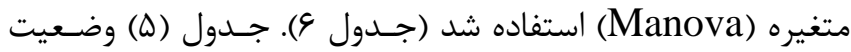

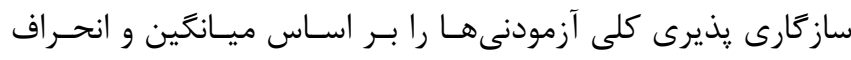

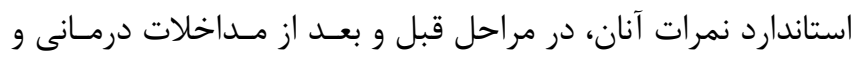

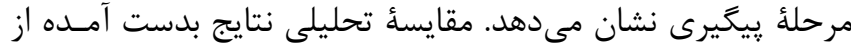

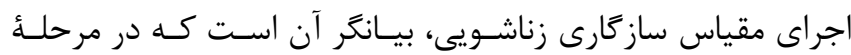

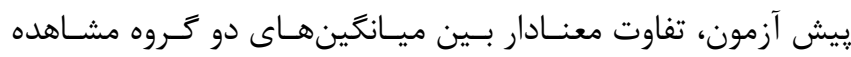

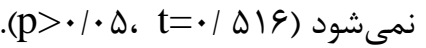

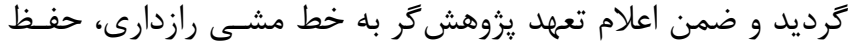

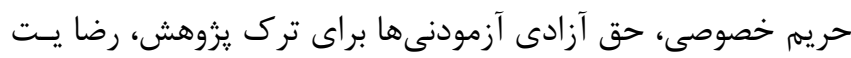

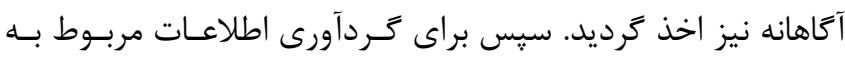

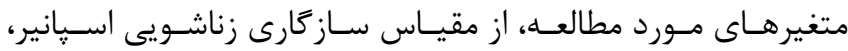

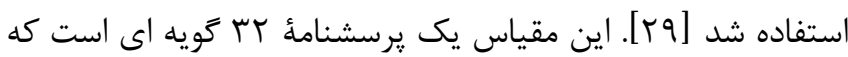

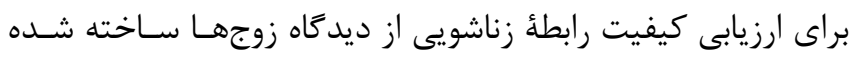

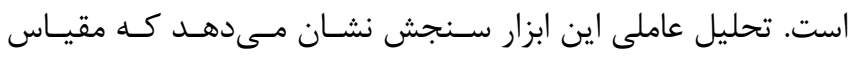

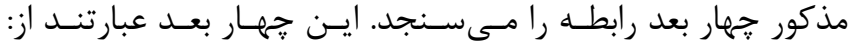

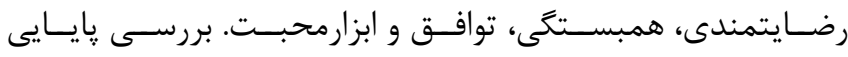

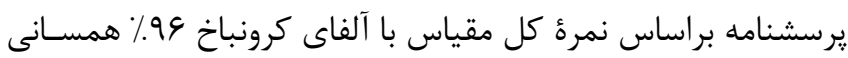

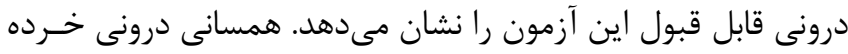

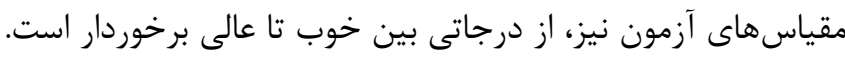

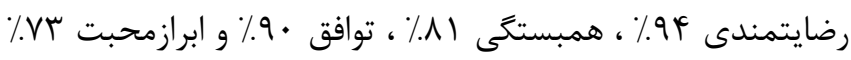

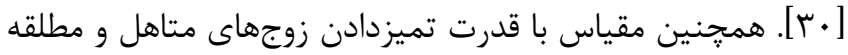

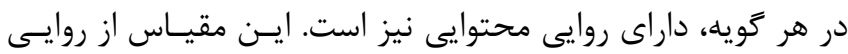

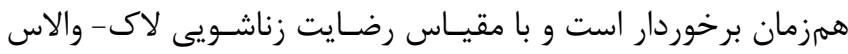

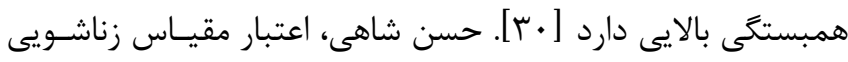

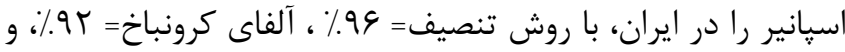

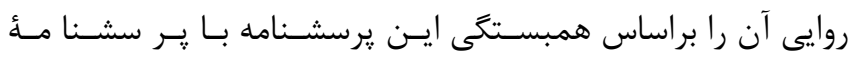

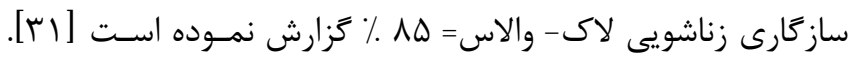

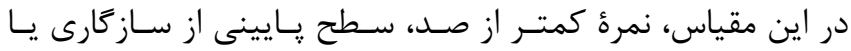

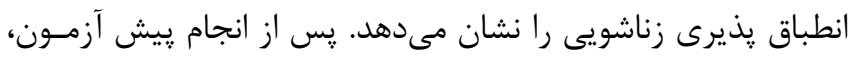

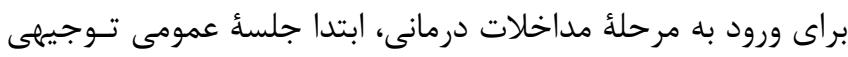

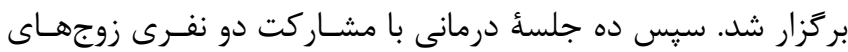

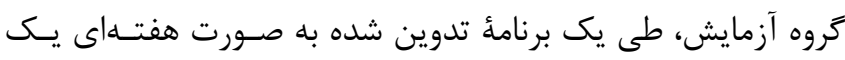

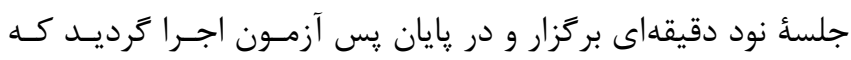

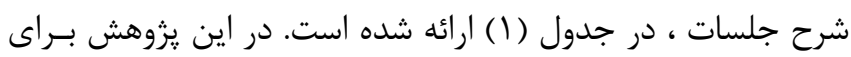

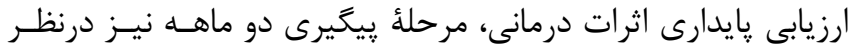

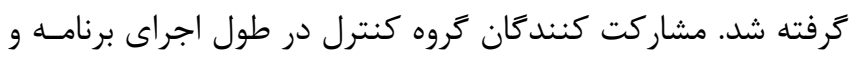

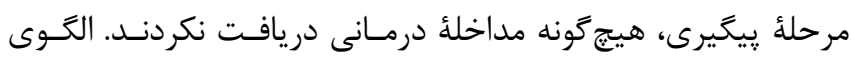

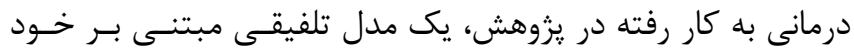

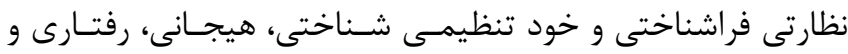

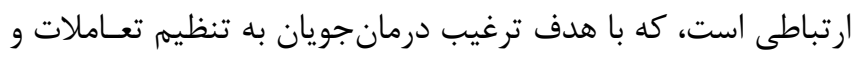

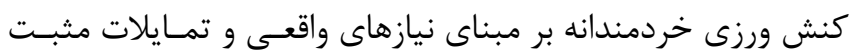
درونى تدوين شده است. دراين يزوهش، به منظور تجزيـهـ و تحليـل

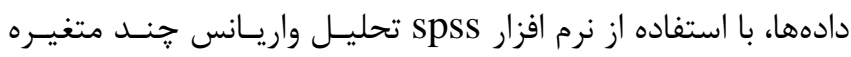


نشريه يروهشكده علوم بهداشتى جهاددانشكاهى

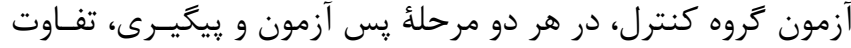

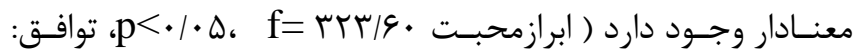

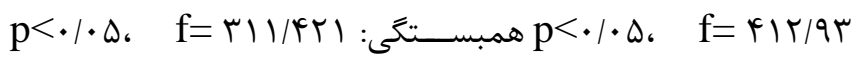

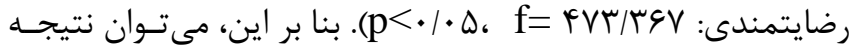

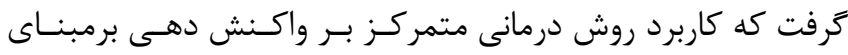

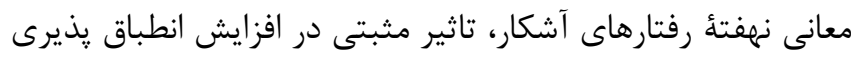
و بهبود مولفههاى سازگارى زناشويى دارد.
معنادارى قابل توجه تفاوت نمرات دو گروه در مرحلة يس از درمان، اثـر بخشى زوج درمانى متمركز بر واكنش دهى بر مبنـاى معـانى نهفتــه در

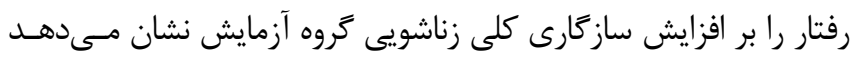

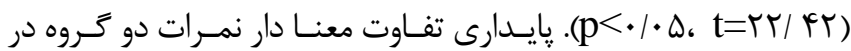

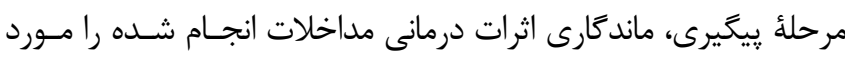

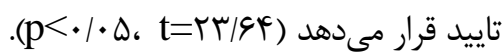

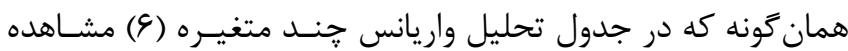

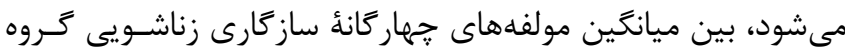

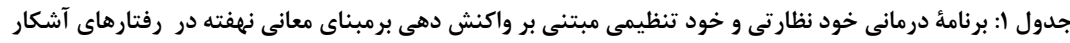

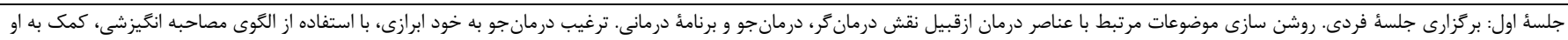

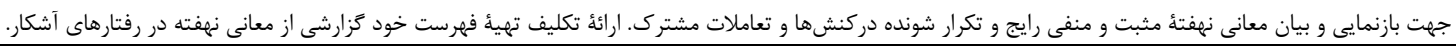

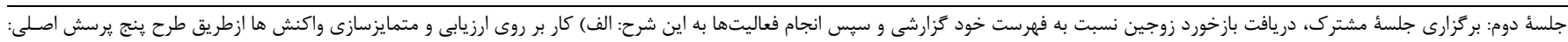

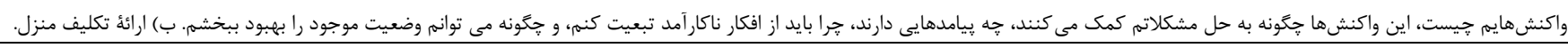

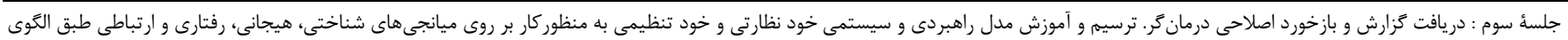

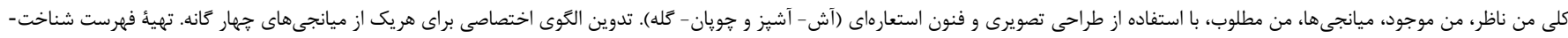

هاى بدكاركرد.

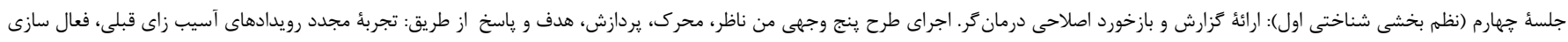

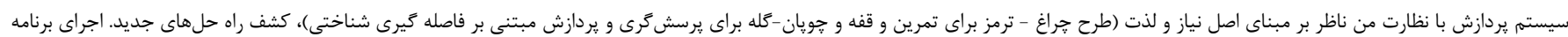
درمنزل.

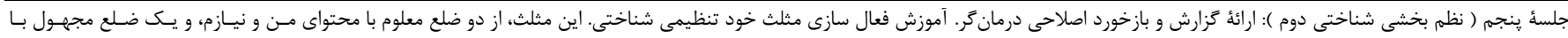

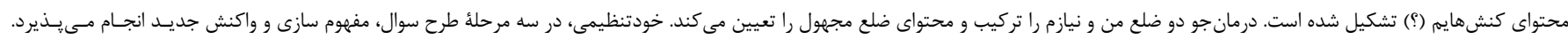
تمرين در منزل.

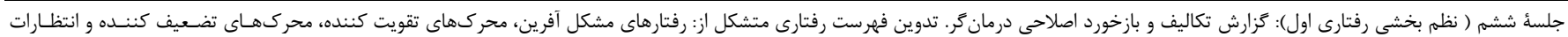

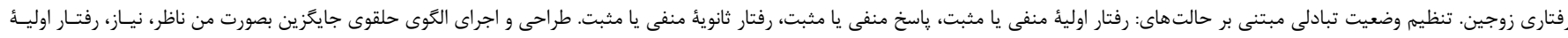

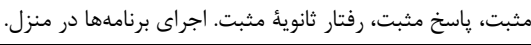

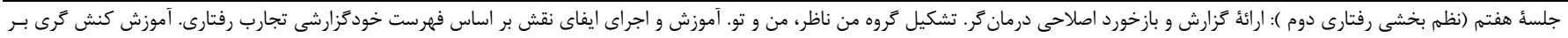

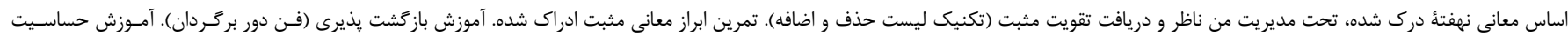

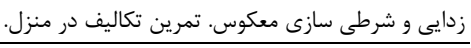

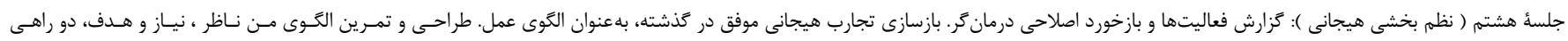

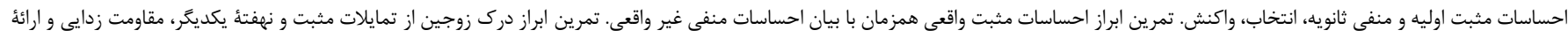

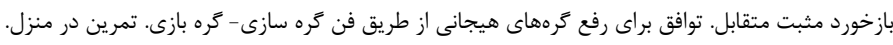

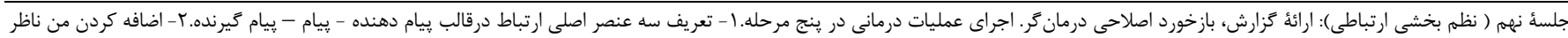

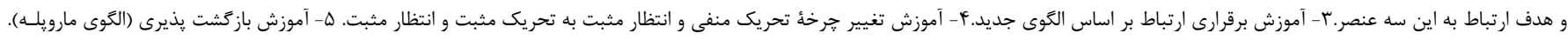
تمرين در منزل.

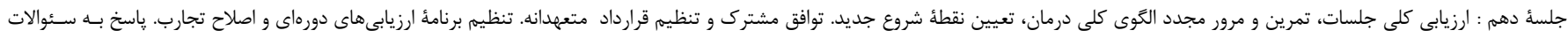

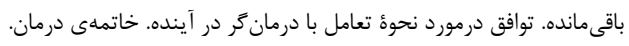

\begin{tabular}{|c|c|c|c|}
\hline & & \multicolumn{2}{|c|}{ جدول r: مشخصات توصيفى سن آزمودنىها به تفكيك جنسيت } \\
\hline & & ميانكَين & انحراف استاندارد \\
\hline \multirow[t]{2}{*}{ كروه آزمون } & مرد & $r T / \Lambda$ & $r / F i$ \\
\hline & 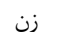 & $r 1 / \Delta$ & $r / 4 \wedge$ \\
\hline \multirow[t]{2}{*}{ كروه كنترل } & مرد & tret & $r / T \Delta$ \\
\hline & زن & ri/s. & $r / r)$ \\
\hline
\end{tabular}


سال بيستم، شماره ششم، آذر -دى .. If

جدول با: توزيع فراوانى سطح تحصيلات در نمونههاى مورد مطالعه

\begin{tabular}{|c|c|c|c|c|}
\hline كروه & & فراوانى & فراوانى درصدى & فراوانى تراكمى \\
\hline \multirow[t]{6}{*}{ آزمون } & دييله & 1 & $19 / V$ & $19 / \mathrm{V}$ \\
\hline & فوق ديڤلم & r & $r \cdot$ & re/V \\
\hline & ليسانس & 10 & $\Delta \cdot$ & $\Lambda \& / V$ \\
\hline & ارشد & r & 1. & $9 \Leftrightarrow / \mathrm{V}$ \\
\hline & دكترى & 1 & $r / r$ & $1 \cdots$ \\
\hline & كل & $r \cdot$ & $1 \cdots$ & \\
\hline \multirow[t]{5}{*}{ كنترل } & دييلم & 9 & $1 \pi / \pi$ & $1 r / r$ \\
\hline & فوق دييلم & $\Delta$ & $r / r$ & re/V \\
\hline & ليسانس & 10 & $\Delta \cdot$ & $\Lambda \varepsilon / V$ \\
\hline & 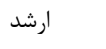 & r & $1 \pi / 4$ & $1 \cdots$ \\
\hline & كل & $r \cdot$ & $1 \cdots$ & \\
\hline
\end{tabular}

جدول f: ميانغين مدت ازدواج و تعداد فرزندان تروه آزمون و كنترل

\begin{tabular}{|c|c|c|c|c|}
\hline كروه & & & مدت ازدواج & فرزندان \\
\hline \multirow[t]{3}{*}{ آزمون } & تعداد & داده پِاسخ & $r$. & $r$. \\
\hline & & نداده ياسخ & · & . \\
\hline & ميانگَين & & $r / 9 V$ & $1 / 4$ \\
\hline \multirow[t]{3}{*}{ كنترل } & تعداد & داده ياسخ & $r$. & $r$. \\
\hline & & نداده پِاسخ & . & . \\
\hline & ميانگَين & & $F / F V$ & $1 / \%$. \\
\hline
\end{tabular}

جدول ه: آزمون تى مستقل براى مقايسهُ ميانعَين نمرات سازگارى زناشويى كلى كروه آزمون وكنترل

\begin{tabular}{|c|c|c|c|c|c|c|c|c|c|}
\hline \multirow[t]{2}{*}{$\mathrm{df}$} & \multirow[t]{2}{*}{$\mathrm{T}$} & \multirow[t]{2}{*}{ Sig } & \multirow[t]{2}{*}{$\mathrm{F}$} & \multicolumn{3}{|c|}{ كروه آزمون } & \multirow{2}{*}{ ميروه كنترل } & \multirow[b]{2}{*}{ آزمون } & \multirow[b]{2}{*}{ متغير } \\
\hline & & & & انحراف استاندارد & ميانگَين & انحراف استاندارد & & & \\
\hline$\Delta \Lambda$ & .1019 & $\cdot / \cdot 1$. & $4 / 19$ & $1 / 9$ & $V N / T$ & $9 / 1$ & $V V / T$ & ييش آزمون & \\
\hline$\Delta \Lambda$ & TT/KT & $\cdot 1 \cdot \cdot 1$ & $\cdot|\Lambda| \Lambda$ & $9 / 4$ & $114 / 99$ & $9 / \pi$ & $V 9 / 9$ & يس آزمون & زناشباق يذيرى \\
\hline$\Delta \Lambda$ & trigt & $.1 \cdot \cdot 1$ & r/vq. & $\Delta / r$ & $11 T / \Lambda 9$ & $4 / 99$ & GN/V & يِيَيرى & \\
\hline
\end{tabular}

جدول و: تحليل واريانس جند متغيره، براى بر رسى تاثير درمان واكنش دهى بر مبناى معانى نهفته، بر مولفههاى سازگًارى زناشويى

\begin{tabular}{|c|c|c|c|c|c|c|c|c|}
\hline \multirow[t]{2}{*}{ df } & \multirow[t]{2}{*}{ مجموع مجذورات } & \multirow[t]{2}{*}{ Sig } & \multirow[t]{2}{*}{$\mathrm{F}$} & \multicolumn{3}{|c|}{ كروه آزمون } & \multirow{2}{*}{ مريانگين كنترل } & \multirow[b]{2}{*}{ آزمون } \\
\hline & & & & انحراف استاندارد & ميانگَين & انحراف استاندارد & & \\
\hline$\Delta \Lambda$ & $F \cdot / f \mid V$ & $.1 \cdot .1$ & TrM/G. & $\cdot \pi$. & $9 / T \& V$ & $\cdot / T \cdot$ & $r / \cdot r$ & ابراز محبت \\
\hline$\Delta \Lambda$ & praq/. & $\cdot 1 \cdot \cdot 1$ & fIr/qr & $\cdot 109$ & $49 / 98$ & $\cdot 109$ & $r q / q$ & 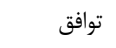 \\
\hline$\Delta \Lambda$ & $V \wedge F / \Lambda I$ &. $\mid \cdot 1$ & TII/FTI & $\cdot / r q$. & $19 / 9$. & $\cdot / r q$. & $9 / \vee$ & همبستخى \\
\hline$\Delta \Lambda$ & $r q \& N / \cdot G$ & $\cdot \mid \cdot 1$ & FVT/TGV & $\cdot / 4 \Delta \lambda$ & rq/1 & $\cdot / 4 \Delta \Lambda$ & $r \Delta / r$ & رضايتمندى \\
\hline
\end{tabular}




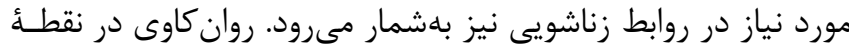

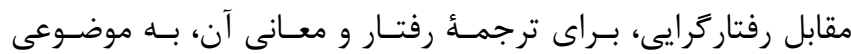

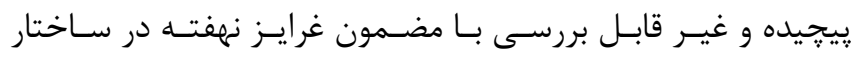

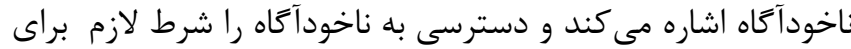

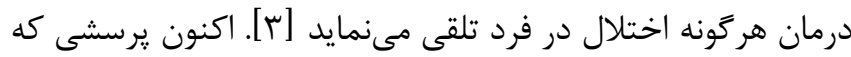

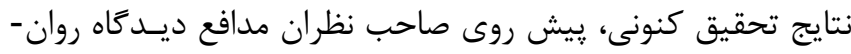

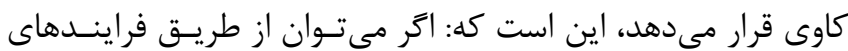

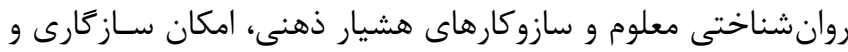

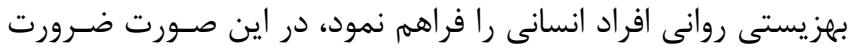

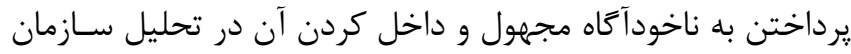

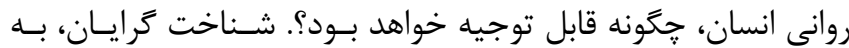
مطالعأ فرايندهاى ذهنى از قبيل باورها، افكار و عقايد مسيردازنـد و

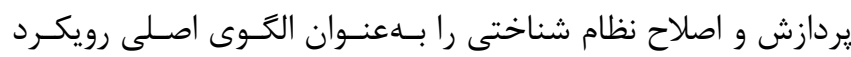

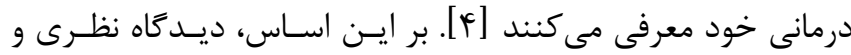

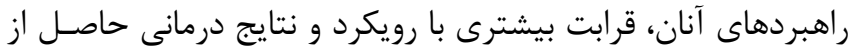

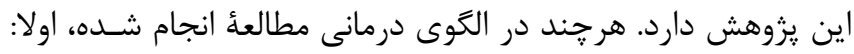

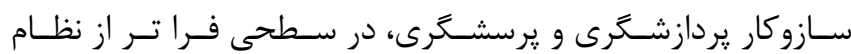

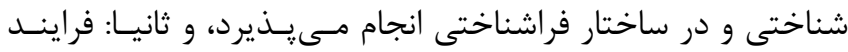

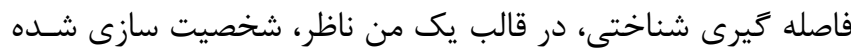

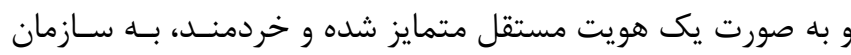

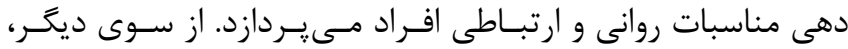

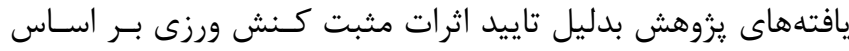

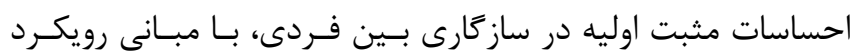

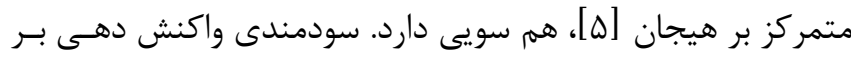

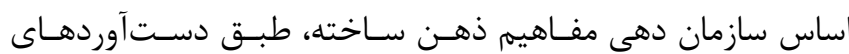

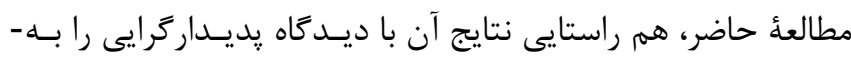

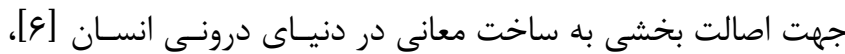

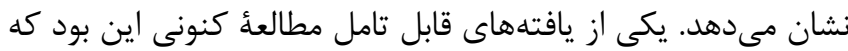

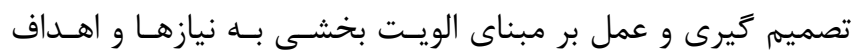

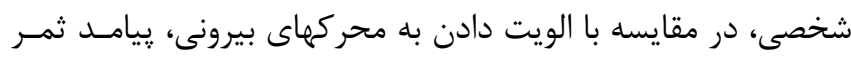

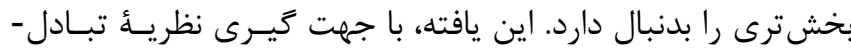

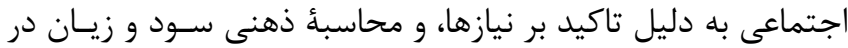

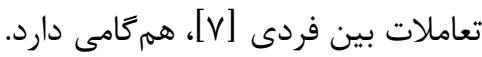

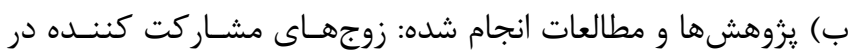
اين تحقيق، پِ ازطى دوره درمانى و ارتقاى سطح خـود نظـارتى و

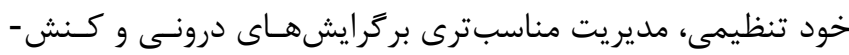

\section{بحث و نتيجه گيرى}

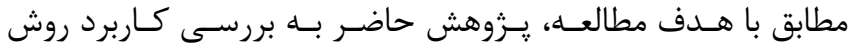

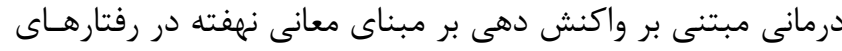

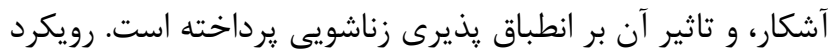

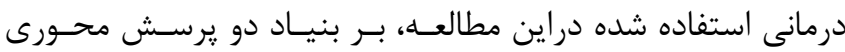
سازمان يافته است كه جرا در اغلب موارد، رفتارهاى انسان با نيازهـا

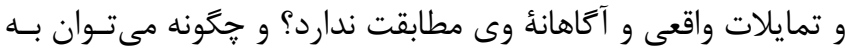

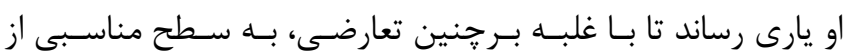
انطباق يافتكى درون فردى و بين فردى نايل كردده؟. نتايج حاصل از از

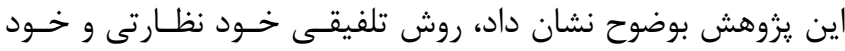

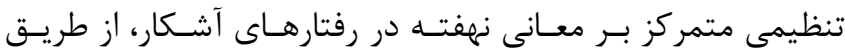
كاهش بازدارىها و تسهيل تعامل هدف محور، بـهـ بهبــود سـاز كارى

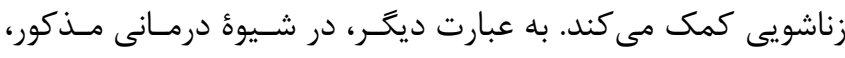

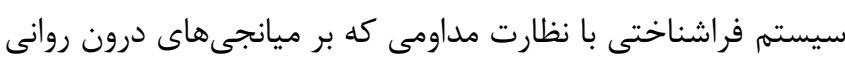
اعمال مى كند، كنشهاى افراد را در خدمت نيازهاى واقعى او اونى

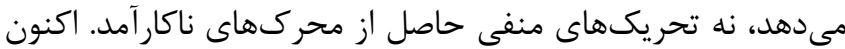

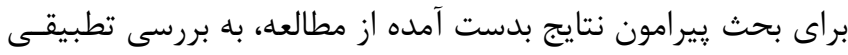

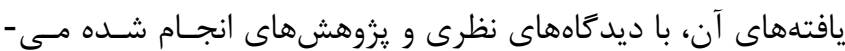

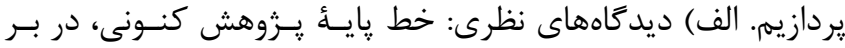

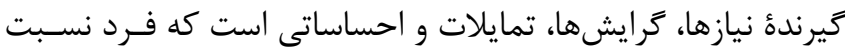

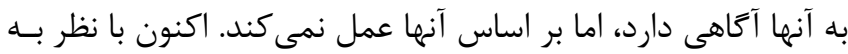

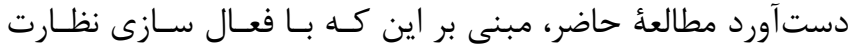

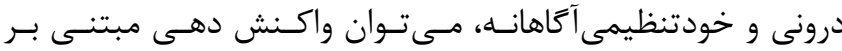

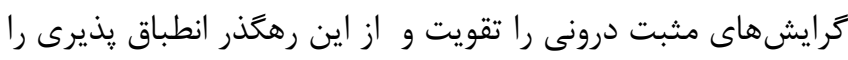

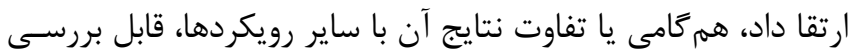
مىشود. يافتههاى اين يزوهش، با ديد

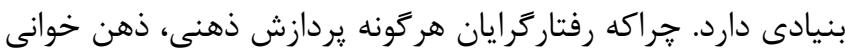

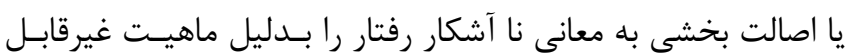

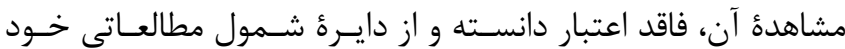

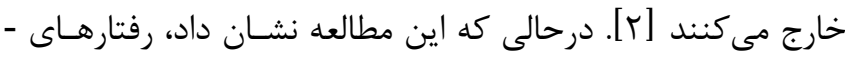

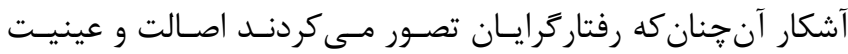
مطلق ندارد، و حتى ممكن است نشانههايى ناكافى يا تحريف شده -

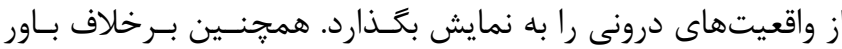

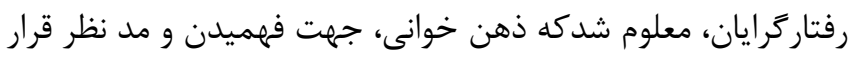

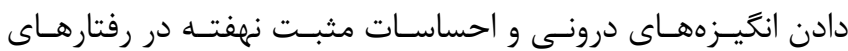

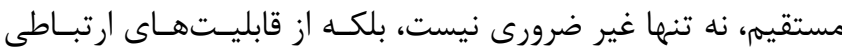


برآيند كلى يافتههاى مطالعهُ انجام شده اين است كه اولا: انسان نـهـ

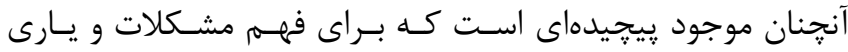

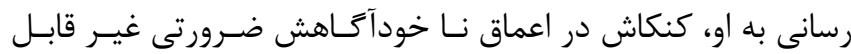

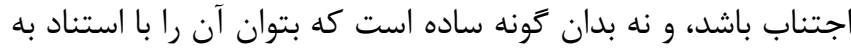
تعدادى نشانهٔ ظاهرى و علائم رفتارى تبيين كـرد. ثانيـا: افـراد ايـن

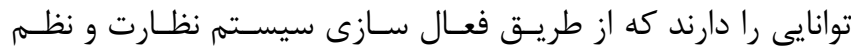

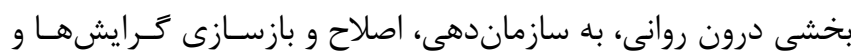

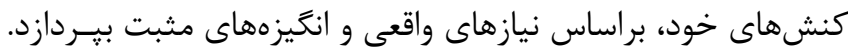

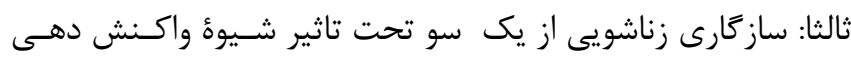

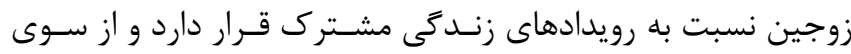

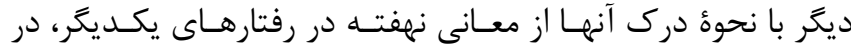

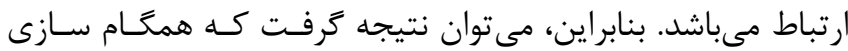

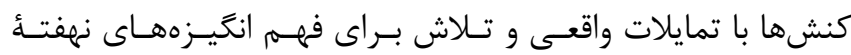

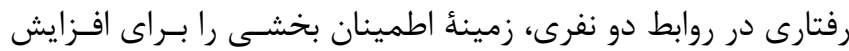
انطباق يذيرى زناشويى فراهم مىنمايد.

\section{سمه نويسند كان}

احد صولت يتلو: نويسنده اصلى، مجرى و نغارندهٔ مقاله

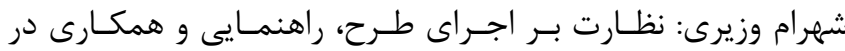
ن نكارش مقاله فرح لطفى كاشانى: نظارت بر اجـــاى طــــ، مشــاوره و همكـارى در ن نخارش مقاله

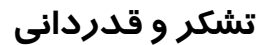
اين مقاله، استخراج شده از رساله دكترى تخصصى با عنوان: كـاربرد

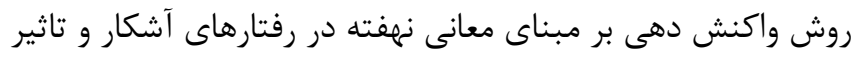
آن بر انطباق يذيرى زناشويى، مصوب دانشكدة روانشناسى دانشعاه

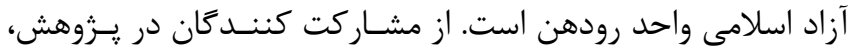

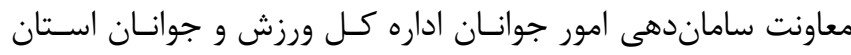
البرز، مديريت و يرسنل مركز خدمات روانشناسى و مشاوره وصـال كرج كه در مراحل مختلف اين تحقيق يارى رسانى كردند، تقـدير و و

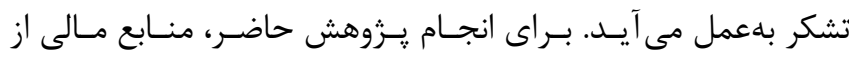
سازمان يا اشخاص حقيقى و حقوقى دريافت نشده است.
هاى بيرونى خود اعمال كردند و بدين ترتيب توانسـتند مولفـهـــاى

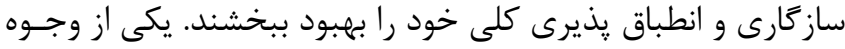
متمايز روش درمانى بكار رفته دراين تحقيق، نكاه تعامل كرايانــأ آن آن

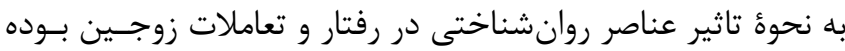

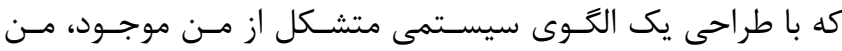

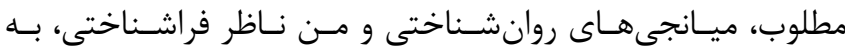
سازماندهى كرايشهاى فردى و تعاملات بين فـردى آنـان يرداختـهـ

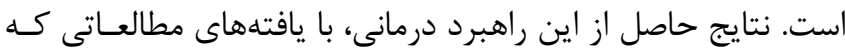

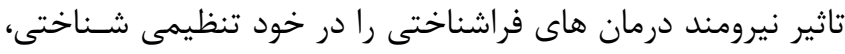

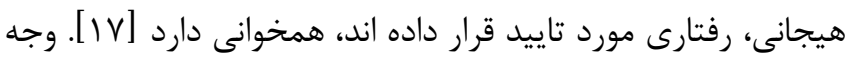

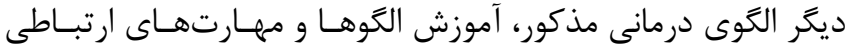

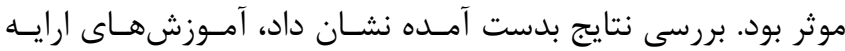

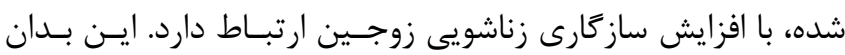

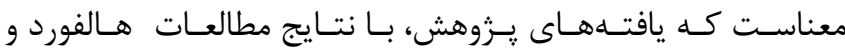

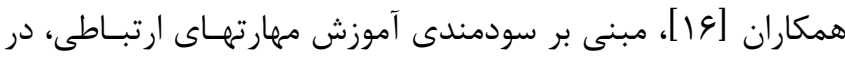

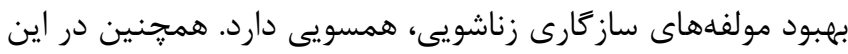

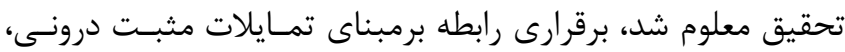

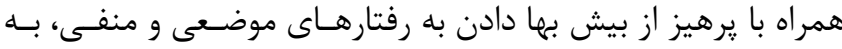
رشد قابل توجهى در ميزان رضايتمندى زناشويى منجر مى آشود. اين

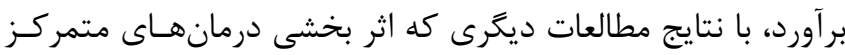

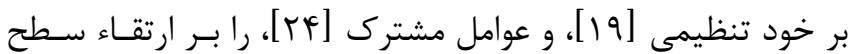
رضايتمندى زناشويى نشان دادهاند، مشابهت دارد. بطور كلى، آنجـهـ

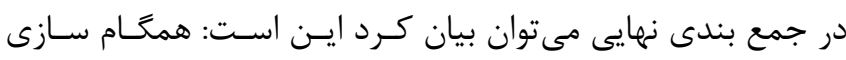

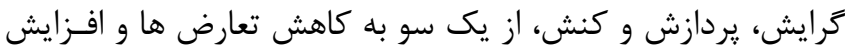

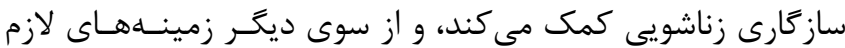

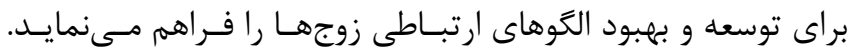
يافتههاى مطالعات مرتبط با برنامئ درمانى مـورد اسـتفاده، كـهـ اثـر بخشى رويكردهاى شناختى رفتارى، بر سازكارى زناشويى و مولفـهـ-

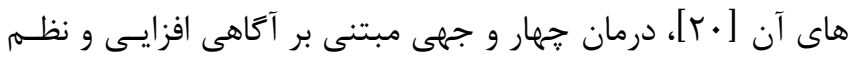

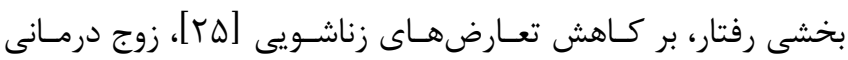

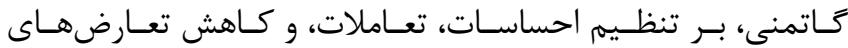

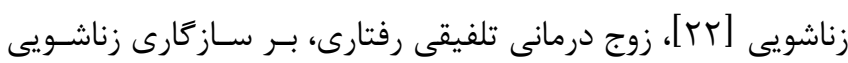

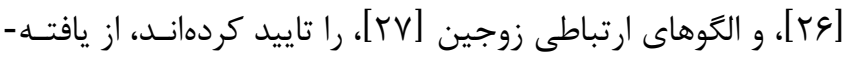
هاى يزوهش حمايت مى كنند. 


\section{منابع}

1. Peña-Ayala A. Metacognition: Fundaments, applications, and trends: A profile of the current stateof- the- $\operatorname{art}$ (Vol. 76). $1^{\text {st }}$ Edition, Springer: USA, 2015

2. Schunk DH. Learning theories: An educational perspective. $6^{\text {st }}$ Edition, Pearson Education, Inc; Boston, 2012

3. Schultz Duane p, Schultz Sydney Ellen. Theorise of pesonality. $10^{\mathrm{st}}$ Edition, Translated by yahya seyed mohammadi: Tehran, 2013[Persian]

4. Moors A. On the causal role of appraisal in emotion. Emotion Review 2013; 2: 132-140. doi.org/10.1177\%2F1754073912463601.

5. Demaree HA, Everhart DE, Youngstrom EA, Harrison DW. Brain Lateralization of emotional processing: Historical roots and a future incorporating "dominance". Behavioral and Cognitive Neuroscience Reviews 2005; $\quad$ 1: 3-20. doi.org/10.1177\%2F1534582305276837

6. Rogers CR. Towards a science of the person. In T. Wann (ED), behaviourism and phenomenology: contrasting bases for modern psychology. $1^{\text {st }}$ Edition, university of Chicago press: USA, 1964

7. Spellman F. The social exchange theory: We all weight out our options. Journal of Personality Assessment 2013; 50: 18-23

8. Fairclough N. Language and power. $2^{\text {st }}$ EditionLongman: UK, 2001

9. Hansen GL. Marital adjustment and conventionalization: A reexamination. Journal of Marriage and Family, 1981; 4: 855-63. Doi:10.2307/351342

10. Bali A, Dhingra R, Baru A. Marital adjustment of childless couples. Journal of Social Sciences 2010; 1 : 73-6. doi: 10.1080/09718923. 2010. 11892839

11. Oulia N, Fatehizadeh M, Bahrami F. The study of effectiveness of instruction marital enrichment on increasing of marital intimacy. Journal of Family Research 2006; 6: 119-135. [ Persian]

12. Durgut S, Kisa S. Predictors of marital adjustment among child brides. Archives of Psychiatric Nursing 2018; 5: 670- 676. doi.org/10.1016/j.apnu. 2018. 03. 006

13. Farahbakhsh K, Shafieabadi A, Ahmadi S, Delavar A. Comparison of effectiveness of rational emotive behavior therapy, reality therapy and electic approach reduction marital conflicts in isfahan. Counceling Research and Development 2006; 18: 3357 [ Persian]
14. Long L, Young G. Counseling and therapy for couples, CA: Thomson Books/Cole Pub, 2006

15. Vulcan M, Shuper E. Body and movement in couple therapy: The intake phase. The Arts in Psychotherapy 2019; 64: 49-58. doi.org/10.1016/j.aip.2019.02.001

16. Halford WK, Lizzio A, Wilson KL, Occhipinti S. Does working at your marriage help? Couple relationship self-regulation and satisfaction in the first 4 years of marriage. Journal Psychology 2007; 2: 185-94. doi: 10.1037/0893-3200 .21. 2.185

17. Rochat L, Manolov R, Billieux J. Efficacy of metacognitive therapy in improving mental health: A meta-analysis of single-case studies. Journal Clinical Psychology 2018; 6: 896-915. doi: 10.1002/ jclp. 22567

18. Welch TS, Lachmar EM, Leija SG, Easley T, Blow AJ, Wittenborn AK. Establishing safety in emotionally focused couple therapy: A single-case process study. Journal of Marital and Family Therapy 2019; 4: 621-634. doi: 10.1111/jmft.12398. [Pub Med: 31355959]

19. Okabayashi H. Self-Regulation, Marital Climate, and Emotional Well-Being among Japanese Older Couples. Cross Cult Gerontol 2020; 4: 433-452. doi: 10. 1007/s10823-020-09409-5

20. Kalkan M, Ersanli E. The Effects of the Marriage Enrichment Program Based on the CognitiveBehavioral Approach on the Marital Adjustment of Couples. Educ. Pract. Theory 2008; 3: 977-86. ERIC Number: EJ837773

21. Kavihta C, Rangan U, Kumar Nirmalan P. Quality of Life and Marital Adjustment after Cognitive Behavioural Therapy and Behavioural Marital Therapy in Couples with Anxiety Disorders. Journal of Clinical and Diagnostic Research 2014; 8: WC01-WC04. doi: 10.7860/ JCDR/2014/9692.4752. [PubMed: 25302250], [PubMed Central: PMC4190 77 6]

22. Gottman J, Tabares A. The effects of briefly interrupting marital conflict. Journal of Marital and FamilyTherapy 2018; 1: 61-72. doi.org/10.1111/jmft. 12243

23. Arianfar N, Etemadi O. The effect of integrated couple therapy based on self- regulation attachment on marital adjustment. Knowledge \& Research in Applied Psychology 2017; 2: 61-71. [Persian]

24. Su-Kubricht LP. The effect of common factor therapist behaviors on ghange in marital satisfaction. 
2018. Theses and Dissertations. 7453. byu. Edu /etd 17453

25. Asem FM, Kashani FL, Vaziri Sh. The effectiveness of four-factor therapy: the relationship of therapy, therapy expectation, increasing awareness and ordered behavior on reducing marriage conflicts. Academic Journal of Interdisciplinary Studies 2017; 2: 119-127 [Persian]

26. Christensen A, Atkins DC, Baucom B, Yi J. Marital status and satisfaction five years following a randomized clinical trial comparing traditional versus integrative behavioral couple therapy. Journal of Consulting and Clinical Psychology 2010; 2: 225-235. doi.org/ 10. 10 37/ a0 018132

27. Perissutti C, Barraca J. Integrative behavioral couple therapy vs. Traditional behavioral couple therapy: A theoretical review of the differential effectiveness. Journal of Clinicaly Saluda 2013; 1: 1118. doi.org/10.5093/cl2013a2

28. DeLongis A, Zwicker A. Marital satisfaction and divorce in couples in stepfamilies. Current Opinion in Psychology 2017; 13: 158-61. doi: 10.1016 /j. copsyc. 2016.11 .003

29. Spanier GB. Measuring dyadic adjustment: New scales for assessing the quality of marriage and similar dyads.Journal of Marriage and Family 1976; 1: 15-28. doi: 10.2307/ 350547

30. Sanai zaker B. Family and maarriage scales. $1^{\text {st }}$ Edition, Besat: Tehran, 2000 [Persian]

31. Soltani M, shaeiri MR, Roshan R. The effect of emotional focused therapy on increasing the marriage stability of barren couples. Journal of Behavioral Sciences 2013; 4: 383-389 [Persian] 